Editor's Note: These short reviews of recent JNeurosci articles, written exclusively by students or postdoctoral fellows, summarize the important findings of the paper and provide additional insight and commentary. If the authors of the highlighted article have written a response to the Journal Club, the response can be found by viewing the Journal Club at www.jneurosci.org. For more information on the format, review process, and purpose of Journal Club articles, please see http://jneurosci.org/content/ preparing-manuscript\#journalclub.

\title{
New Insights on the Role of Residue 673 of APP in Alzheimer's Disease
}

\author{
-Matthew C. Mueller, ${ }^{1} \oplus^{-B}$ Bradley J. Baranowski, ${ }^{2}$ and ${ }^{-G r a n t ~ C . ~ H a y w a r d ~}{ }^{2}$ \\ ${ }^{1}$ Department of Biological Sciences and ${ }^{2}$ Department of Health Sciences, Brock University, St. Catharines, Ontario, Canada L2S 3A1 \\ Review of Zhang et al.
}

\begin{abstract}
Alzheimer's disease (AD) is the most common neurodegenerative disorder and its two major pathological hallmarks are neuritic plaques and neurofibrillary tangles (Benilova et al., 2012; Ward et al., 2012). The formation of neuritic plaques through the aggregation of amyloid- $\beta(\mathrm{A} \beta)$ oligomers is thought to be foundational to the pathophysiology of $\mathrm{AD}$ according to the amyloid cascade hypothesis (Hardy and Selkoe, 2002). Amyloid precursor protein (APP), existing as three major isoforms (APP695, APP751, and APP770), can be processed through two major pathways (Nalivaeva and Turner, 2013) (Fig. 1). In the nonamyloidogenic pathway, APP is first cleaved by $\alpha$-secretase at the Leu ${ }^{17}$ site, resulting in membrane-bound C83 and a secreted soluble APP fragment, s-APP $\alpha$ (Esch et al., 1990). Next, C83 is cleaved by $\gamma$-secretase to produce a C-terminal fragment (CTF $\gamma$ ) and P3 (Vardy et al., 2005). In the amyloidogenic pathway, APP is initially cleaved by $\beta$-secretase, also known as $\beta$-site APP cleaving enzyme 1 (BACE1), which can cleave APP at one of two distinct sites, the major $\mathrm{Glu}^{682}$ or the minor Asp ${ }^{672}$ site, which are
\end{abstract}

Received Sept. 19, 2017; revised Nov. 12, 2017; accepted Nov. 20, 2017. We thank Dr. Rebecca MacPherson and Dr. Aleksandar Necakov for comments on the manuscript.

The authors declare no competing financial interests.

Correspondence should be addressed to Matthew C. Mueller, Depart-

ment of Biological Sciences, Brock University, 1812 Sir Isaac Brock Way, St. Catharines, Ontario, Canada L2S 3A1. E-mail:mm13zk@brocku.ca.

DOI:10.1523/JNEUROSCI.2710-17.2017

Copyright $\odot 2018$ the authors $\quad 0270-6474 / 18 / 380515-03 \$ 15.00 / 0$ commonly referred to as the Glu ${ }^{11}$ and Asp ${ }^{1}$ sites because of their corresponding positions on $\mathrm{C} 99 / \mathrm{C} 89$ and $\mathrm{A} \beta$. This results in secreted $\operatorname{sAPP} \beta$ and a membrane-bound C-terminal fragment $\beta(\mathrm{CTF} \beta)$. Cleavage at the $\mathrm{Glu}^{11}$ site forms a C-terminal fragment that is 89 residues in length (C89), which, after $\gamma$-secretase cleavage, results in a truncated form of $\mathrm{A} \beta$. Cleavage by BACE1 at the Asp ${ }^{1}$ residue, however, creates a C-terminal fragment that is 99 residues long (C99), which generates $\mathrm{A} \beta$ after cleavage by $\gamma$-secretase.

Most cases of AD are considered sporadic, but some cases $(<1 \%)$ are classified as familial AD (FAD). Some cases of FAD are caused by point mutations in the genes that code for APP (Bekris et al., 2010). A well studied FAD-causing mutation is the dominantly inherited Swedish mutation, $\mathrm{APP}_{\text {Swe }}$, which leads to increased C99 levels. Another FAD mutation, found in an Italian family, is inherited recessively and characterized by an alanine to valine missense mutation at residue $673(\mathrm{~A} 673 \mathrm{~V})$ of APP770 ( $\left.\mathrm{APP}_{\text {rIta }}\right)$. Upon cleavage by BACE1 and $\gamma$-secretase, the A673V mutation can be found on C99 and $A \beta$ on the second residue, which is referred to as an $\mathrm{A} 2 \mathrm{~V}$ mutation (Fig. 1). There is currently limited knowledge about the molecular processes that link these APP mutations to the pathogenic manifestation of AD. A recent study by Zhang et al. (2017) published in the The Journal of Neuroscience addressed this question by investigating the role of residue 673 of APP in BACE1 cleavage site selection and APP processing in the context of amyloidogenesis in AD.

Zhang et al. (2017) investigated whether $\mathrm{APP}_{\text {rIta }}$ led to increased C99 production that translated into increased levels of $\mathrm{A} \beta$. Adeno-associated viruses containing wildtype APP $\left(\mathrm{APP}_{\mathrm{WT}}\right)$ or $\mathrm{APP}_{\mathrm{rIta}}$ were injected into brains of neonatal mice. An antibody specific for the last 20 residues of the APP C terminus was used to examine the relative levels of C83, C89, and C99. The $\mathrm{APP}_{\text {rIta }}$ A673V mutation resulted in higher C99 levels and C99/C89 ratios compared with $\mathrm{APP}_{\mathrm{WT}}$. This suggests that the $\mathrm{A} 673 \mathrm{~V}$ mutation shifted the dominant BACE1 cleavage in APP from the Glu ${ }^{11}$ site to the Asp ${ }^{1}$ site, a result consistent with previous research (Kimura et al., 2016). Zhang et al. (2017) then examined the effects of $\mathrm{APP}_{\text {rIta }}$ and $\mathrm{APP}_{\text {Swe }}$ in vitro using $\mathrm{PC} 12$ rat pheochromocytoma cells and a BACE1 stable cell line, 293B2. They showed that $\mathrm{APP}_{\text {rIta }}$ cleavage generated more C99 fragment than $\mathrm{APP}_{\mathrm{WT}}$ and $\mathrm{APP}_{\text {Swe }}$ and therefore had a stronger effect than $\mathrm{APP}_{\text {Swe }}$ in shifting the preferential $\beta$-cleavage site from Glu $^{11}$ to Asp ${ }^{1}$.

Despite $\mathrm{APP}_{\mathrm{rIta}}$ cleavage producing more C99 than the $\mathrm{APP}_{\text {Swe }}$ mutation, Zhang et al. (2017) discovered that the $\mathrm{APP}_{\text {rIta }}$ cleavage pathway produced less $\mathrm{A} \beta 40$ and $\mathrm{A} \beta 42$ than $\mathrm{APP}_{\text {Swe }}$ (although still more than $\left.A P P_{W T}\right)$. To determine why this is the case, the researchers investigated the fate of C99 after BACE1 cleavage. HEK293 cells ex- 


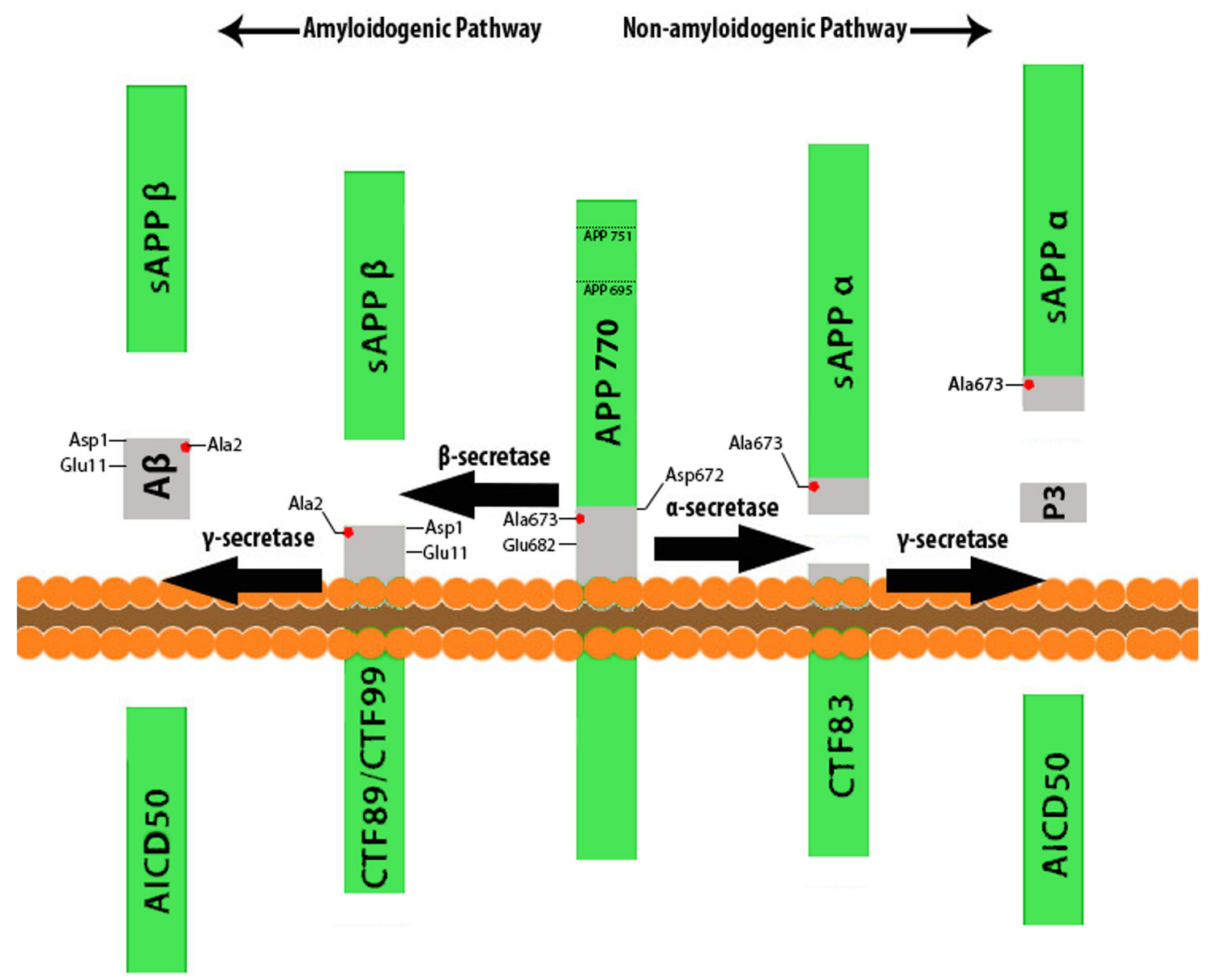

Figure 1. APP can be cleaved through amyloidogenic or non-amyloidogenic pathways. In the non-amyloidogenic pathway, $\alpha$-secretase cleaves APP to form sAPP $\alpha$ and CTF83. In the amyloidogenic pathway, APP is cleaved by $\beta$-secretase (BACE1) at either the Glu ${ }^{11}$ site to form CTF89, resulting in a truncated form of A $\beta$, or the Asp ${ }^{1}$ site to make CTF99, which is cleaved by $\gamma$-secretase to form A $\beta$ (gray). The Ala673 site of APP becomes the Ala ${ }^{2}$ site (red) of A $\beta$.

pressing either $\mathrm{C} 99_{\mathrm{WT}}$ or $\mathrm{C} 99_{\mathrm{A} 2 \mathrm{~V}}$, the C99 fragment resulting from cleavage of the $\mathrm{APP}_{\text {rIta }}$ mutation, were treated with a $\gamma$-secretase inhibitor, a lysosome inhibitor, or a proteasome inhibitor. The $\gamma$-secretase inhibitor resulted in an $\sim 184 \%$ increase of C99 ${ }_{\mathrm{WT}}$, whereas $\mathrm{C} 99_{\mathrm{A} 2 \mathrm{~V}}$ only increased by $\sim 53 \%$. In contrast, the proteasome inhibitor resulted in a 25 -fold increase in $\mathrm{C} 99_{\mathrm{A} 2 \mathrm{~V}}$ compared with only an eightfold increase in C99 ${ }_{\text {WT }}$. These findings suggest that the A673V mutation enhances C99 degradation by the proteasome and decreases cleavage by $\gamma$-secretase compared with C99 ${ }_{\mathrm{WT}}$.

Finally, Zhang et al. (2017) investigated the overall effect of APP residue 673 on BACE1 cleavage. Another mutation at the same residue of APP, A673T, was previously discovered to be protective against $\mathrm{AD}$ in the Icelandic population (Jonsson et al., 2012). Knowing that mutation of this site could be either protective or FAD causing, the investigators substituted the hydrophobic alanine on site 673 of APP770 with a range of amino acids including negatively charged aspartic acid, structurally rigid proline, positively charged arginine, hydrophobic leucine, and polar uncharged glutamine and serine. They then used immunoblotting to examine the CTF cleavage profiles after $\beta$-cleavage. These point mutations all reduced C99 levels and increased C89 and C83 levels compared with WT, with the exception of leucine, which shares characteristics with valine and alanine in that they are short-chain alkane residues. In general, these findings imply that cleavage of APP by $\alpha$-secretase is enhanced by these mutations and that the preferential BACE1 cleavage site is shifted to the Glu682 site of APP.

Compared with the $\mathrm{APP}_{\text {Swe }}$ mutation, $\mathrm{APP}_{\text {rIta }}$ results in less $\mathrm{A} \beta$ generation; however, patients still develop severe FAD pathology. A reason for this discrepancy might be the difference in $\mathrm{A} \beta$ composition: the $\mathrm{APP}_{\text {rIta }}$ mutation occurs in the $\mathrm{A} \beta$ peptide $\left(\mathrm{A} \beta_{\mathrm{A} 2 \mathrm{~V}}\right)$, but the $A P P_{\text {Swe }}$ mutation does not (it produces $\mathrm{A} \beta_{\mathrm{WT}}$ ). Giaccone et al. (2010) compared these peptides and discovered that $\mathrm{A} \beta_{\mathrm{A} 2 \mathrm{~V}}$ in a homozygous form had higher aggregation kinetics and more stable $\mathrm{A} \beta$ assemblies than $A \beta_{\mathrm{WT}}$ (Giaccone et al., 2010). The rIta mutation is thought to form amyloid aggregates more rapidly, thus triggering the downstream cascade of effects leading to neurotoxicity.

The findings of Zhang et al. (2017) provide insight into the role of APP residue 673 in FAD. They show that a single mutation from alanine to valine can affect BACE1 cleavage site selection, resulting in disproportionately high C99 production but lower $\mathrm{A} \beta$ production relative to $\mathrm{APP} \mathrm{Swe}_{\text {we }}$. Regarding the fate of $\mathrm{C} 99_{\mathrm{A} 2 \mathrm{~V}}$ after initial $\beta$-cleavage, the investigators revealed that the fragment has reduced $\gamma$-secretase cleavage and increased proteasomal degradation. Together, the results presented by Zhang et al. (2017) suggest site 673 of APP as a therapeutic target. Zhang et al. (2017) showed the 673-residue site to be a key determinant between the amyloidogenic and non-amyloidogenic pathways, as demonstrated in the $\mathrm{A} 673 \mathrm{~V}$ and $\mathrm{A} 673 \mathrm{~T}$ mutations, respectively. To determine why heterozygous carriers of $\mathrm{APP}_{\text {rIta }}$ did 
not develop FAD, Di Fede et al. (2009) investigated the interaction between $\mathrm{A} \beta_{\mathrm{A} 2 \mathrm{~V}}$ generated as a result of the $\mathrm{APP}_{\text {rIta }}$ cleavage pathway and $\mathrm{A} \beta_{\mathrm{WT}}$. They showed that this interaction in a heterozygous form had a protective effect against $\mathrm{A} \beta$ aggregation compared with both $\mathrm{A} \beta_{\mathrm{A} 2 \mathrm{~V}}$ and $\mathrm{A} \beta_{\mathrm{WT}}$ on their own (Di Fede et al., 2012, 2016). Using this information, Di Fede et al. (2016) developed a synthetic rIta peptide $\left(\mathrm{A} \beta 1-6_{\mathrm{A} 2 \mathrm{~V}}\right)$. The peptide was then tested in mouse and in vitro models, where it interacted with $\mathrm{A} \beta_{\mathrm{WT}}$ and showed beneficial interference with $A \beta$ oligomer production (Di Fede et al., 2016). The methods discussed here and results by Zhang et al. (2017) provide the groundwork for future investigations into how APP mutations have broader implications for $\mathrm{AD}$ and for the development of treatment strategies.

\section{References}

Bekris LM, Yu CE, Bird TD, Tsuang DW (2010) Genetics of Alzheimer disease. J Geriatr Psychiatry Neurol 23:213-227. CrossRef Medline Benilova I, Karran E, De Strooper B (2012) The toxic $\mathrm{A} \beta$ oligomer and Alzheimer's disease: an emperor in need of clothes. Nat Neurosci 15: 349-357. CrossRef Medline
Di Fede $\mathrm{G}$ et al. (2009) A recessive mutation in the APP gene with dominant-negative effect on amyloidogenesis. Science 323:1473-1477. CrossRef Medline

Di Fede G, Catania M, Morbin M, Giaccone G, Moro ML, Ghidoni R, Colombo L, Messa M, Cagnotto A, Romeo M, Stravalaci M, Diomede L, Gobbi M, Salmona M, Tagliavini F (2012) Good gene, bad gene: new APP variant may be both. Prog Neurobiol 99:281-292. CrossRef Medline

Di Fede G, Catania M, Maderna E, Morbin M, Moda F, Colombo L, Rossi A, Cagnotto A, Virgilio T, Palamara L, Ruggerone M, Giaccone G, Campagnani I, Costanza M, Pedotti R, Salvalaglio M, Salmona M, Tagliavini F (2016) Tackling amyloidogenesis in Alzheimer's disease with $\mathrm{A} 2 \mathrm{~V}$ variants of amyloid- $\beta$. Sci Rep 6:20949. CrossRef Medline

Eggert S, Midthune B, Cottrell B, Koo EH (2009) Induced dimerization of the amyloid precursor protein leads to decreased amyloid-beta protein production. J Biol Chem 284:2894328952. CrossRef Medline

Esch FS, Keim PS, Beattie EC, Blacher RW, Culwell AR, Oltersdorf T, McClure D, Ward PJ (1990) Cleavage of amyloid $\beta$ peptide during constitutive processing of its precursor. Science 248:1122-1124. CrossRef Medline

Giaccone G, Morbin M, Moda F, Botta M, Mazzoleni G, Uggetti A, Catania M, Moro ML, Redaelli V, Spagnoli A, Rossi RS, Salmona M, Di Fede G, Tagliavini F (2010) Neuropathology of the recessive A673V APP mutation:
Alzheimer disease with distinctive features. Acta Neuropathol 120:803-812. CrossRef Medline

Hardy J, Selkoe DJ (2002) The amyloid hypothesis of Alzheimer's disease: progress and problems on the road to therapeutics. Science 297: 353-356. CrossRef Medline

Jonsson T, et al. (2012) A mutation in APP protects against Alzheimer's disease and agerelated cognitive decline. Nature 488:96-99. CrossRef Medline

Kimura A, Hata S, Suzuki T (2016) Alternative selection of $\beta$-site APP-cleaving enzyme 1 (BACE1) cleavage sites in amyloid $\beta$-protein precursor (APP) harboring protective and pathogenic mutations within the $\mathrm{A} \beta$ sequence. J Biol Chem 291:24041-24053. CrossRef Medline

Nalivaeva NN, Turner AJ (2013) The amyloid precursor protein: a biochemical enigma in brain development, function and disease. FEBS Lett 587:2046-2054. CrossRef Medline

Vardy ER, Catto AJ, Hooper NM (2005) Proteolytic mechanisms in amyloid-beta metabolism: therapeutic implications for Alzheimer's disease. Trends Mol Med 11:464-472. CrossRef Medline

Ward SM, Himmelstein DS, Lancia JK, Binder LI (2012) Tau oligomers and tau toxicity in neurodegenerative disease. Biochem Soc Trans 40:667-671. CrossRef Medline

Zhang S, Wang Z, Cai F, Zhang M, Wu Y, Zhang J, Song W (2017) BACE1 cleavage site selection critical for amyloidogenesis and Alzheimer's pathogenesis. J Neurosci 37:6915-6925. CrossRef Medline 